\title{
Editorial Introduction: Fascist and National Socialist Antiquities and Materialities from the Interwar Era to the Present Day
}

\author{
Helen Roche \\ Durham University, UK \\ helen.b.roche@durham.ac.uk \\ Flaminia Bartolini \\ University of Cambridge, UK \\ fb282@cam.ac.uk \\ TimothyJ. Schmalz \\ University of Cambridge, UK \\ ts633@cam.ac.uk
}

\begin{abstract}
Fascist Italy and Nazi Germany, along with other twentieth-century authoritarian regimes, have often attempted to create consensus through propagandistic reinterpretations of the classical past. The Fascist appropriation of romanità and Nazi philhellenism were not only conditioned by prior cultural receptions of antiquity, but were also a key political tool in motivating and mobilising citizens to fulfil the aims of the fascist state. Once Fascism and Nazism had fallen, the material legacies of both regimes then became the object of destruction, reinterpretation and memory work. Thus, the archaeological and architectural heritage of these regimes, now tainted by their ideology, has not only suffered the consequences of damnatio memoriae in the aftermath of regime change, but continues even today to inflame contemporary public debate. This special issue represents the product of an interdisciplinary workshop exploring these themes, which was held at Sidney Sussex College, Cambridge, on 8 June 2018.
\end{abstract}

\section{Keywords}

Italy - Germany - Fascism - National Socialism - romanità - philhellenism

(C) HELEN ROCHE ET AL., $2019 \mid$ DOI:10.1163/22116257-00802007

This is an open access article distributed under the terms of the prevailing CC-BY-NC license at the time of publication. 
Fascist Italy and Nazi Germany, along with other twentieth-century authoritarian regimes, have often attempted to create consensus through propagandistic reinterpretations of the classical past. As recent scholarship has shown, the Fascist appropriation of romanità and Nazi philhellenism were not only conditioned by prior cultural receptions of antiquity, but were also a key political tool in motivating and mobilising citizens to fulfil the aims of the fascist state. ${ }^{1}$ Once Fascism and Nazism had fallen, the material legacies of both regimes then became the object of destruction, reinterpretation and memory work. Thus, the archaeological and architectural heritage of these regimes, now tainted by their ideology, has not only suffered the consequences of damnatio memoriae in the aftermath of regime change, but continues even today to inflame contemporary public debate.

This special issue represents the product of an interdisciplinary workshop exploring these themes, which was held at Sidney Sussex College, Cambridge, on 8 June 2018, organised by Helen Roche, Flaminia Bartolini, and Timothy J. Schmalz, and funded by the DAAD Cambridge Hub and the Department of History, University of Cambridge. The workshop brought together a group of international experts, including historians of Germany and Italy, classicists, archaeologists, and art historians, to explore the complex relationships between antiquity and materiality, both during and after Fascism and National Socialism.

The first session, focusing on Fascist and National Socialist Antiquities, included a synoptic paper by Jan Nelis on 'Fascist and National Socialist Classicism', followed by more specific case studies on 'Architecture and Material Culture in the Latin Literature of the ventennio fascista' (Han Lamers and Bettina Reitz-Joosse) and 'German Philhellenism and the Reception of Winckelmann during the Third Reich' (Helen Roche). The second session, on Fascist and National Socialist Materialities, featured a paper by Joshua Arthurs entitled 'Burning Paper and Crushing Bedbugs: Iconoclasm, Memory and Expectation during the Fall of Mussolini', as well as presentations by Clare Copley and Flaminia Bartolini, on 'National Socialist Prestige Buildings and the Postwar Urban Landscape' and 'Renegotiating the Fascist Past in Contemporary Italy'. The workshop concluded with a round-table discussion featuring Hannah Malone, Martijn Eickhoff, James Fortuna, and Donna Storey, chaired by Aristotle Kallis.

In his survey of the issues raised by the round-table debate and ensuing open discussion, Joshua Arthurs noted that there appeared to be a welcome

1 cf. e.g. Helen Roche and Kyriakos Demetriou, ed., Brill's Companion to the Classics, Fascist Italy and Nazi Germany (Leiden: Brill, 2018). 
consensus among all participants to the effect that fascist material culture still mattered, and that classicism and recourses to the ancient past were central to the cultural projects of both Nazism and Fascism. This state of affairs arguably stands in salutary contrast to the state of scholarship a decade or two ago, which, in the Italian case, focused almost exclusively on the avant-garde, modernist dimensions of Fascist culture, while scholarship on National Socialism tended to emphasise the importance of völkisch ideology. The crucial role played by classicists and mid-ranking intellectuals and functionaries, who drove much of this discourse (as opposed to Mussolini and Hitler, or even Piacentini and Speer) clearly formed a fruitful new sphere of enquiry; all in all, the complexities of cultural production under both regimes were illuminated afresh. The presentations also successfully applied many of the tools of classical studies - including philological, archaeological, artistic and architectural analysis - to the modern context.

Issues related to the themes in hand which could profitably bear further exploration, in Arthurs' view, include: ${ }^{2}$

The question of the producers and their intellectual background: Many of the individual scholars and intellectuals considered in the case studies presented here could more accurately be classified as pre-Fascist or pre-Nazi conservatives, who were drawing on a repository of longstanding and entrenched discourses, rather than dyed-in-the-wool ideologues. To what extent, then, are some scholars right when they characterise classicism as a concession to the reactionary establishment, rather than an expression of the 'revolutionary', modernist thrust of these ideologies?

The question of audiences and reception: In many cases, the audience for classicising works was limited to a fairly small body of elites - whether scholars, intellectuals, or political hierarchs. How did classicism translate into the mass culture promoted by both regimes? Did it matter as much in this setting?

Questions of representation versus reality: Jan Nelis reiterated Emilio Gentile's argument that, to understand fascism, one must approach it through its own words. This has yielded much productive research on culture and representation, especially in an Italian context. However, it can also result in a conflation between what these regimes said about themselves and what they actually did. To cite just one example, pointing to the 'Square Colosseum' and the buildings of EUR as successful manifestations of romanità is problematic. These were dreamed up and begun under Fascism, but were completed and

2 The points below represent a slightly reworked version of Joshua Arthurs' informal report on the closing discussion (private correspondence with Helen Roche, 29 June 2018). 
populated in the postwar period. In other words, they never functioned in the way that the regime intended; this problematises the notion that their intended 'message' was self-evident to viewers. Or one might compare Fascism's discourse on Mare nostrum and empire with the realities of its disastrous and brutal policies in Africa and the Mediterranean; these are often bracketed off as separate issues, but are fundamentally intertwined.

What is the relevance of Fascist and Nazi classicism for understanding classicism today? To what extent is our contemporary conception of classical civilisation filtered through a 'totalitarian' lens - for example, the enduring legacies of Fascist urbanism in Rome, or the revaluation of interwar architecture? We might think of film and TV portrayals of antiquity that present Greece and Rome as disciplined, hierarchical, warrior societies (such as 300 or Gladiator), consisting only of gleaming monumental spaces, crowds saluting and chanting the leader's name, and so forth. This can also work in a negative sense - i.e. the rejection of classicism and classical studies as hopelessly tarnished by associations with nationalism, ethnocentrism and imperialism.

The issue of finding 'solutions' to 'tainted' material culture: For a long time, scholars have approvingly pointed out the creativity and subtlety of the German approach to architectural manifestations of the Nazi past - for example, the 'calculated neglect' of the Nuremberg Rally grounds, combined with its new documentation centre. However, there seems to be a growing sense that installing a series of placards does not inoculate these sites from problematic associations, and that they are often ignored or overlooked by passers-by. Has this 'historicizing' approach exhausted itself? In a 'post-fact' universe, is it still effective to bombard the viewer with context and explanation? What alternate approaches are possible? What does it mean to 'solve' this 'problem'?

How can we best manage our tendency to focus on the political resonance of fascist materiality, to the exclusion of all other considerations? Often, those who are making the case that a building is 'only' a building, or that it should be appreciated only for its aesthetic qualities, are the very same people who seek to valorise the fascist past, or (especially in the German case) who call for a 'moving on' that includes the abandonment of pluralism and liberal democracy. In other words, a 'colour-blind' position on these sites is far from neutral. There are also important distinctions to be made between new projects - such as, in the Italian case, the Museum of Fascism at Predappio - and reactions to previously existing fascist material culture. The latter can be more multivalent and ambivalent, and have been subject to shifting discourses over the decades; the former is an intervention in the present, much more readily ascribable to a given political agenda.

The articles in this special issue do not attempt to provide a definitive answer to these questions, but rather explore them from a number of varying 
perspectives. Thus, Helen Roche's article on 'classicising chronopolitics' in Mussolini's Italy and Hitler's Germany seeks to identify and analyse continuities in nationalist appeals to the ancient past over the longue durée, suggesting that the Fascist recourse to romanità and the Nazi recourse to philhellenism in fact represented the culmination or radicalisation of pre-existing national traditions which had also existed prior to unification. From this perspective, an analysis of fascist classicism can provide a discrete example of the way in which fascisms tend to appropriate the ideas and traditions which lie ready to hand in the nationalist canon, creating what we might term a 'fascist national vernacular'. Nicolò Bettegazzi, Han Lamers and Bettina Reitz-Joosse's analysis of Francesco Giammaria's Capitolium Novum, which emphasises the material Rome's multivalency as a site of Catholic as well as fascist imaginaries, then provides a tellingly detailed case study of Fascist classicism's indebtedness to prior intellectual and generic developments, as well as documenting a significant example of Fascist romanità in the (latinising) literary sphere. James J. Fortuna's article then explores a rather different form of (often explicitly classicising) staged materiality - that of the plans and pavilions destined for the 1939 New York World's Fair.

Clare Copley's article then sets out to explore the controversial material legacies of the National Socialist and Fascist past. Copley analyses postreunification discourses relating to the preservation of the Nazi 'layers' of Berlin's urban palimpsest, focusing on the former Aviation Ministry, the Olympic Stadium, and Tempelhof Airport. Finally, Samuel Agbamu explores the genesis and rhetorical antecedents of two Italian humanitarian operations codenamed 'Mare Nostrum' and 'Mos Maiorum', which were instigated during the recent Mediterranean refugee crisis, and which reveal some startling continuities in Fascist and post-Fascist political rhetoric and colonial fantasies. Agbamu's paper was first presented at the Institute of Classical Studies, University of London, at the 'Claiming the Classical' (стс) Network's inaugural 'Mapping Workshop' on 9 November 2018, which 'mapped' how Greco-Roman antiquity is being deployed in twenty-first-century political rhetoric, identifying differences across national and continental boundaries, as well as across the political spectrum. ${ }^{3}$ The стс network was established by Naoíse Mac Sweeney and Helen Roche in 2018, in order to facilitate collaborative international research on the use of the classical world in contemporary political rhetoric. GrecoRoman antiquity, far from being irrelevant in the twenty-first century, is

3 For an extensive report on the workshop's findings, see Naoíse Mac Sweeney et al., 'Claiming the Classical: The Greco-Roman World in Contemporary Discourse,' Council of University Classical Departments Bulletin 48 (2019), accessed November 29, 2019, https://claimingtheclassicalnet.files.wordpress.com/2019/02/mac-sweeney-et-al-claiming-the-classical.pdf. 
regularly invoked in current political discourse; from the Spartan imagery used by white supremacists in the USA, or 'identitarians' in Europe, to comparisons between imperial Rome and China, classical antiquity occupies a powerful place in the contemporary political imagination. These politicised 'claims on the classical' shape public perceptions of antiquity, as well as influencing developments within academia. Thus, understanding them is crucial both for political and cultural commentators, as well as for classical researchers and enthusiasts. The Стс network therefore aims to understand and engage with current political appropriations of the classical past. What impact do such appropriations have on the wider public understanding of antiquity? Should academics and researchers engage with such appropriations, in what contexts, and how? ${ }^{4}$

Ultimately, taken together, the contributions in this special issue aim both to provide a multifaceted examination of various aspects of the reception of antiquity under dictatorial regimes, and to reflect upon the fate of fascist material legacies from the aftermath of the Second World War to the present day. We therefore hope that the modes of analysis and conclusions contained therein may stimulate further discussion and debate upon these perennially intertwined themes, whether among scholars of other nations and regimes, or those in different academic disciplines.

4 For more information on the network, and on how to join, see https://claiming-the-classical .org/. 